UDC 546.661.5

\title{
NITROGEN FIXATION AT CONJUGATED OXIDATION
}

\author{
${ }^{1,2}$ T.M.Nagiev, ${ }^{1}$ N.I.Ali-zadeh, ${ }^{1}$ L.M.Gasanova, ${ }^{2}$ I.T.Nagieva, ${ }^{1}$ Ch.A.Mustafaeva \\ ${ }^{1}$ N.N.Malikova, ${ }^{1}$ A.A.Abdullaeva, ${ }^{1}$ E.S.Bakhramov \\ ${ }^{1}$ Nagiev Institute of Catalysis and Inorganic Chemistry, NAS of Azerbaijan \\ ${ }^{2}$ Baku State University \\ tnagiev@azeurotel.com
}

Received 05.02.2018

\begin{abstract}
Using the new principle of nitrogen oxidation by hydroperoxide has helped in discovering a new method of nitrogen fixation, mainly shaped as $\mathrm{N}_{2} \mathrm{O}$, other oxides with low admixtures or nitrogen-containing acids under conditions, which are relatively soft for such reaction type. Gas-phase oxidation of nitrogen with hydrogen peroxide is rather complicated and consists of primary nitrous oxide formation. When nitrous oxide with the reaction mixture is yielded by the reaction (high-temperature) zone, it enters secondary reactions with other reagents in the mixture and, on rapid cooling, forms $\mathrm{H}_{2} \mathrm{~N}_{2} \mathrm{O}_{2}$ and other nitrous acids.
\end{abstract}

Keywords: nitrogen, fixation, hydrogen peroxide, nitrous oxide, nitrous acid.

\section{Introduction}

The problem of nitrogen fixation is one of the most important scientific and technical tasks. The nitrogen and nitrogen-compound-making industry is one of the leading branches of the modern chemical industry. The state of the art of it is the main factor affecting the supply of nitrogenous fertilizers to agriculture and of various nitrogen-containing substances to industry.

\section{Overview}

D.I.Mendeleev was the first to bring up the question of nitrogen fixation from air: time will come, when nitrogen compounds will be produced from air nitrogen. This will be a great success for practiced life, because having nitrogen compounds and using them as fertilizers one can obtain high crops of cultivated plants. One of the tasks of applied chemistry is searching for technically advantageous method of obtaining nitrogen compounds containing assimilable nitrogen from the air nitrogen. The fortune of agriculture is mostly dependent on discovery of such a method.

It is common knowledge that both shapes of mineral bound nitrogen-ammonia and nitrateare directly accessible for plants. Therefore, at present, the question of nitrogen fixation in inorganic compounds is urgent. The problem is that human and animal organisms are unable to use nitrogen from inorganic compounds for protein synthesis. As for nitrogen nutrition, its resources are limited by assimilating activity of plants and weed-eating animal proteins. Therefore, meeting human and animal demand for proteins depends on the level of meeting the demand of plants for mineral fixed nitrogen.

The following methods of nitrogen fixation are developed: ammonia, arc, cyanamide, plasmatic, thermal and nitric oxides synthesis in a nuclear reactor. However, besides ammonia synthesis, no other methods have found wide industrial application. This method has many disadvantages, for example: multistage type and production awkwardness, the necessity for specific materials, equipment and machinery suitable for working under high pressure and temperature conditions, inexpensive raw material demand in the form of natural gas, coke oven gas or petroleum residues, high investments, etc. Therefore, research into new, simple and more economic methods of atmospheric nitrogen fixation are continuing. Direct air nitrogen oxidation can be implemented at high temperatures and under the influence of high velocity electrons and -y-radiation, in a nuclear reactor, etc.

Thermal oxidation of nitrogen was studied by Gabor Nemst, Zeldovich and others [1]. Various methods of atmospheric nitrogen ther- 
mal fixation in regeneration ovens and reactors of various constructions and principles of operation were suggested. The essence of all methods consists in obtaining equilibrium values of nitric oxide concentrations at different temperature modes. In a plasma jet, bulk mean air temperature can simply be raised to 3000 $4000 \mathrm{~K}$ and pressure boosted to several tens of atmospheres. This increases nitric oxide concentration in nitrous gas to 5\%. Compared with the ammonia method, the advantage of the plasmatic method is the presence of almost inexhaustible resources of raw materials, simplicity of formation and an opportunity for plant construction in close proximity to the customer.

Among methods of nitrogen chemical fixation, direct nitrogen oxidation by air oxygen giving nitric oxide is of special attention for application purposes. The wide distribution of the initial products and their low cost are obvious. The problem is reduced to reaction implementation with the lowest costs. In the USA, the Bradley-Lovejoy [2] method of atmospheric nitrogen fixation by oxygen in a high-voltage discharge was applied in industry.

Stokes and Knipe obtained nitric oxides by mixing nitrogen plasma jet with gen. The average conversion of $\mathrm{O}_{2}$ in these experiments equaled 2\%. La Roche [3] obtain higher yields in high-quality discharge plasma. Maximal concentration in a sample with low quenching rate just slightly exceeded $2 \%$. The use of devices providing high quenching rate NO concentration above $4 \%$ which testifies to the importance of quenching for this process.

A possibility of NO synthesis from the air was studied [4]. Fromens used thermal reaction, the so-called Wisconsin process, which at maximal temperature $2500 \mathrm{~K}$ gave an NO yield equals $1.9 \%$ and at $1900 \mathrm{~K}$ - below $0.45 \%$.

Thompson [4] described a thermal process in a flow oven with a temperature up $3000 \mathrm{~K}$. Under favorable experimental conditions, NO concentration in nitrous gases reached $3.7 \%$.

Analysis of the works in which NO formation is studied [5] in the nitrogen-oxygen system at high temperature shows NO concentrations ranging within $2-4 \%$.
There were experiments [6] studying formation of nitric oxides in nitrogen plasma jet with injected oxygen, oxygen-nitrogen mixture and water. In this case, NO concentration in nitrous gases reached $8 \%$.

According to data by Polak and Shipachev, the main object of expenditure in the production of nitrogen from air in plasma jets is electric power.

The works by Volpin and Shur [7] as well as by Shilov [8] on molecular nitrogen fixation via complexing with transition metals indicates nitrogen readily reacting with low-valence organometallic compounds of titanium, chromium, molybdenum, wolfram andiron.

More investigations of nitrogen reactions with transition metal compounds confirmed the capability of nitrogen to readily enter reactions and reduction by many organometallic and inorganic coordination compounds of transition metals.

Shilov et al. [9] displayed the possibility of synthesizing stable ruthenium complex with molecular nitrogen.

Thus, at present, the task of atmospheric nitrogen fixation has mainly been developed in two directions: reduction and oxidation fixation. Chemical fixation of molecular nitrogen by the reduction mechanism on transition metals is a comprehensively studied branch of physical chemistry, displaying several discoveries made in this direction [10].

Meanwhile, another direction, that of oxidative fixation of nitrogen, has been poorly studied, because only several oxidation reactions are known; for example, the above-described reactions in electric arc, plasma or induced by ionizing radiation [11]. They are all endothermic oxidation reactions, consuming high energy and possessing low selectivity and yield.

The analytical analysis in methods of nitrogen fixation methods prompts the conclusion that all currently existing techniques possess specific disadvantages. Therefore, besides modernization of synthetic ammonia production process, new methods of molecular nitrogen fixation are also searched for. In this connection, of interest is the development of chemicalengineering processes in which conjugated reaction principles will be used and, therefore, 
non-spontaneous oxidative fixation of nitrogen will be implemented with the help of chemical induction (similar to biological systems).

\section{Experimental part and discussion}

As shown below, the application of this principle to nitrogen oxidation by hydroperoxide has helped in discovering a new method of nitrogen fixation, mainly shaped as $\mathrm{N}_{2} \mathrm{O}$, other oxides with low admixtures or nitrogen-containing acids under conditions, which are relatively soft for such reaction type. The method is also energy saving and ecologically friendly $[12,13]$.

For the sake of comparison, let us briefly consider the commonly known method of nitrous oxide synthesis by thermal decomposition of ammonia nitrate at $523-533 \mathrm{~K}$ by the following reaction:

$$
\mathrm{NH}_{4} \mathrm{NO}_{3} \Leftrightarrow \mathrm{N}_{2} \mathrm{O}+2 \mathrm{H}_{2} \mathrm{O} .
$$

Admixtures are 1-2\% nitrogen and NO, which can be removed by passing bivalent iron sulfate through the solution. Moreover, $\mathrm{N}_{2} \mathrm{O}$ is also produced by nitrates and nitrites reduction under definite conditions or by hyponitrite decomposition.

It is shown [14] that besides $\mathrm{N}_{2} \mathrm{O}$, an acid suggested to be hyponitrous acid $\left(\mathrm{H}_{2} \mathrm{~N}_{2} \mathrm{O}_{2}\right)$ is formed in the aqueous part of products of molecular nitrogen oxidative fixation with hydrogen peroxide. This acid then dissociates to $\mathrm{N}_{2} \mathrm{O}$ and $\mathrm{H}_{2} \mathrm{O}$. Acid formation is also indicated by predominant presence of $\mathrm{N}_{2} \mathrm{O}$ in the aqueous phase in amounts significantly exceeding its solubility in water. The presence of soft acid (which is $\mathrm{H}_{2} \mathrm{~N}_{2} \mathrm{O}_{2}$ ) may be judged by changes in the $\mathrm{pH}$ of the solution (3-4). Hence, direct detection of $\mathrm{H}_{2} \mathrm{~N}_{2} \mathrm{O}_{2}$ was reduced to qualitative reaction of yellow-colored silver hyponitrite $\left(\mathrm{Ag}_{2} \mathrm{~N}_{2} \mathrm{O}_{2}\right)$ precipitation [15]. Taking into account the fact that silver cation also gives a yellow deposit with nitrite anion $\mathrm{NO}_{2}^{-}$. As well as some technical difficulties associated with $\mathrm{Ag}_{2} \mathrm{~N}_{2} \mathrm{O}_{2}$ (which is an extremely unstable salt) extraction from the solution, titration by lithium and potassium hydroxides was performed in one part of the reaction product. Hyponitrites of lithium and potassium hydroxides display high thermal stability up to $260^{\circ} \mathrm{C}$ [16]. X-ray diffraction analysis of these salts, extracted by solvent evaporation, showed the presence of $\mathrm{NO}_{2}^{-}$and $\mathrm{NO}_{3}^{-}$anions in them shaped as $\mathrm{KNO}_{2}$, $\mathrm{KNO}_{3}$ and $\mathrm{LiNO}_{3} \cdot 2 \mathrm{H}_{2} \mathrm{O}$. According to the analyses discussed below, the main part of these salts consists of alkaline metal hyponitrites.

In alkaline metal salts, hyponitrite-ion $\mathrm{N}_{2} \mathrm{O}_{2}$ was detected using IR-spectroscopy technique (by the presence of intensive absorption bands at 500 and $1000 \mathrm{~cm}^{-1}$ ) [16] and from qualitative reactions.

$\mathrm{HJ}$ and starch action. As HJ and starch are poured into a potassium hyponitrite solution, the latter is colored blue $2-3 \mathrm{~min}$ afterwards, which is a result [16] of insignificant amounts (traces) of $\mathrm{NO}_{2}$ anion presence, which were formed in the following reactions [16, 17]:

$$
\begin{gathered}
3 \mathrm{~K}_{2} \mathrm{~N}_{2} \mathrm{O}_{2}+2 \mathrm{H}_{2} \mathrm{O} \Leftrightarrow 2 \mathrm{KNO}_{2}+2 \mathrm{KOH}+2 \mathrm{~N}_{2}, \\
\mathrm{~K}_{2} \mathrm{~N}_{2} \mathrm{O}_{2}+\mathrm{O}_{2}=2 \mathrm{KNO}_{2} .
\end{gathered}
$$

The action of concentrated $\mathrm{H}_{2} \mathrm{SO}_{4}$. Potassium hyponitrite decomposes completely under the effect of concentrated $\mathrm{H}_{2} \mathrm{SO}_{4}$. The reaction is outrage and releases nitrous oxide, which unambiguously indicates its origin, because interaction with $\mathrm{H}_{2} \mathrm{SO}_{4}, \mathrm{KNO}_{2}$ and $\mathrm{KNO}_{3}$ does not release $\mathrm{N}_{2} \mathrm{O}$. The main reaction is described by the following equation:

$$
\mathrm{K}_{2} \mathrm{~N}_{2} \mathrm{O}_{2}+\mathrm{H}_{2} \mathrm{SO}_{4}=\mathrm{K}_{2} \mathrm{SO}_{4}+\mathrm{H}_{2} \mathrm{O}+\mathrm{N}_{2} \mathrm{O} \text {. }
$$

Oxidation with $\mathrm{KMnO}_{4}$. The solution used contained $0.2 \mathrm{~g} \mathrm{KMnO}_{4}$ and $30 \mathrm{ml} \mathrm{H}_{2} \mathrm{SO}_{4}$. As $\mathrm{K}_{2} \mathrm{~N}_{2} \mathrm{O}_{2}$ and $\mathrm{KNO}_{2}$ were poured into the solution, it became colorless. Then for the purpose of $\mathrm{HNO}_{3}$ detection, which may be formed in the reactions below [16], the aliquot part was extracted:

$$
\begin{aligned}
& \mathrm{H}_{2} \mathrm{~N}_{2} \mathrm{O}_{2} \stackrel{\mathrm{O}_{2}}{\longrightarrow} \mathrm{HNO}_{3}, \\
& \mathrm{HNO}_{3} \stackrel{\mathrm{O}_{2}}{\longrightarrow} \mathrm{HNO}_{2} .
\end{aligned}
$$

In the case, when only $\mathrm{KMnO}_{4}$ solution ( $0.2 \mathrm{~g}$ in $\left.30 \mathrm{ml} \mathrm{H}_{2} \mathrm{SO}_{4}\right)$ is poured to the mixture, outrage release of gases is observed. Chromatographic analysis of these gases indicated the presence of equal parts of $\mathrm{N}_{2} \mathrm{O}$ and $\mathrm{N}_{2}$. After pouring $\mathrm{H}_{2} \mathrm{SO}_{4}$ to the system this ratio shifts toward nitrous oxide. 
Thus, the results of above analyses of aqueous reaction products and salts extracted by hydroxide titration indicate the presence of $\mathrm{N}_{2} \mathrm{O}_{2}^{-}$, $\mathrm{NO}_{2}^{-}$and $\mathrm{NO}_{3}^{-}$anions in the reaction products.

The latter anion can also be obtained in another reaction [17]:

$$
\mathrm{KNO}_{2}+\mathrm{K}_{2} \mathrm{~N}_{2} \mathrm{O}_{2}+\mathrm{H}_{2} \mathrm{O}=\mathrm{KNO}_{3}+2 \mathrm{KHOH}+\mathrm{N}_{2} \text {. }
$$

It may be concluded from generalized results that the conjugated reaction of molecular nitrogen oxidative fixation with hydrogen peroxide mostly produces nitrous oxide $\left(\mathrm{N}_{2} \mathrm{O}\right)$ in concentrations below $19 \%$. In the quenching zone, most of the nitrous oxide is converted to $\mathrm{H}_{2} \mathrm{~N}_{2} \mathrm{O}_{2}$ due to the action of active sites $\left(\mathrm{HO}_{2}^{\circ}\right.$ and $\left.{ }^{\circ} \mathrm{OH}\right)$ and $\mathrm{H}_{2} \mathrm{O}_{2}$. Small amounts of $\mathrm{HNO}_{2}$ and $\mathrm{HNO}_{3}$ (up to $0.1 \%$ ) are also detected [18].

Figure shows the dependence of molecular nitrogen conversion on its volume rate in the temperature range of $773-873 \mathrm{~K}$. It is clearly observed that the quantity of fixed nitrogen per injected molecular nitrogen increases to some extent with the amount of injected molecular nitrogen. A further increase of raw material rate does not change the level of nitrogen fixation. Despite shorter contact time, the increase of $\mathrm{N}_{2}$ volume rate from 1 to $4 \mathrm{l} / \mathrm{h}$ intensifies the reaction.

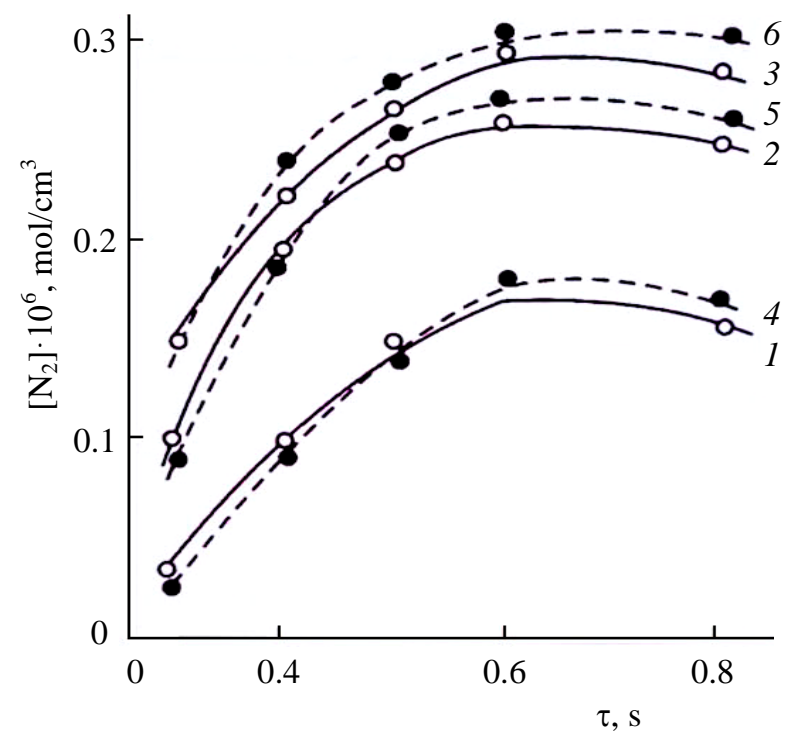

Kinetics of nitrogen fixation with hydrogen peroxide: 1-3: at $T=773,823$ and $873 \mathrm{~K}$ respectively; 4-6theoretical curves at these temperatures. Molar ratio $\mathrm{N}_{2}: 30 \% \mathrm{H}_{2} \mathrm{O}_{2}=1: 1.6$.
The aqueous hydroperoxide rate is constant for all nitrogen rates. However, at a nitrogen rate of $4-5 \mathrm{l} / \mathrm{h}$ the fixed nitrogen yield is altered.

Thus, chemical induction is the main factor promoting $\mathrm{N}_{2}$ fixation in a $\mathrm{N}_{2}-\mathrm{H}_{2} \mathrm{O}_{2}-\mathrm{H}_{2} \mathrm{O}$ system. It manifests itself owing to conjugation of $\mathrm{H}_{2} \mathrm{O}_{2}$ dissociation reactions, which generate the intermediate $-\mathrm{HO}_{2}^{\circ}$ radical - to the system. This intermediate transfers the induction action of the primary reaction to the $\mathrm{N}_{2}$ oxidation process. In this case, $\mathrm{H}_{2} \mathrm{O}_{2}$ is injected in amounts much greater than demanded by $\mathrm{N}_{2}$ oxidation, because the main requirement for effective chemical conjugation is the presence of $\mathrm{HO}_{2}^{*}$ in high concentration.

To conclude the discussion, it should be noted that oxidative fixation of molecular nitrogen with hydrogen peroxide is fairly simple for process-engineering design, usually proceeds under homogeneous conditions without any catalyst under atmospheric pressure, and produces high yields of fixed nitrogen.

Among other aims, the author attempted in this chapter to give a simple phenomenological description of the kinetic regularities of conjugated oxidation with hydrogen peroxide in the gas phase with time, plotted as curves in the figures above. Thus, the quantitative data accumulated in kinetic investigations must be transformed to qualitatively absolutely different results, associated with the decoding of the chemical conjugation mechanism in reactions of oxidation with hydrogen peroxide and the basic principles of its operation.

This work was supported by the Science Development Foundation under the President of the Republic of Azerbaijan - Grant № EIFKETPL-2-2015-1(25)-56/18/4.

\section{References}

1. Atroshchenko V.I., Alekseev A.M., Zasorin A.P. Kurs tekhnologii sviazannogo azota. M.: Himiia, 1969. $384 \mathrm{~s}$.

2. Curtis H.A. Fixed Nitrogen. No 4. The Chem. Cataloqueco. 1932. Chap. 4. 463 p.

3. La Roche N.G., Etude de la torche electronique, la chemie des hautes temperatures. Proc. CNRS, 1955. $212 \mathrm{p}$.

4. Thomson A.L., Formation and quen-ching of nitric oxide in a continuous flow furnace. Spring 
Meeting of Western States Combustion Institute. 1965. P. 243.

5. Polak L.S. Ispolzovanie plazmy v himicheskikh protcessakh. M.: Nauka, 1970. $253 \mathrm{~s}$.

6. Guliaev G.V., Kozlov G., Polak L.S. Kinetika i termodinamika himicheskikh reaktcii v nizkotemperaturnoi plazme. M.: Nauka, 1965. S. 132-151.

7. Volpin M.E., Shur V.B. Fiksatciia azota na kompleksnykh katalizatorakh // Docl. AN SSSR. 1964. T. 156. № 5. S. 1102-1105.

8. Shilov A.E. Fiksatciia azota $\mathrm{v}$ rastvorakh $\mathrm{v}$ prisutstvii kompleksov perehodnykh metallov //Uspehi himii. 1974. T. 43. № 5. S. 863-902.

9. Shilov A.K., Shilov A.E., Brodko Yu.G. Obrazovanie kompleksov molekuliarnogo azota s soedineniiami ruteniia i osmiia //Docl. AN SSSR. 1967. T. 176. № 6. S. 1297-1299.

10. Hardy R., Bottomli F. Problemy fiksatcii azota. M.: Mir, 1982. 734 s.

11. Chatt Dzh., Kamara P., Richards R. Novoe v himicheskoi fiksatcii azogta. M.: Mir, 1983. 304 s.

12. Nagiev M.F., Nagiev T.M., Bairamov V.M., Iskenderov R.A. Sviazyvanie azota v vide ego zakisi // Docl. AN SSSR. 1973. T. 213. № 5. S. 1096-1098.
13. Nagiev T.M., Shakhtakhtinskii T.N. Sopriazhennaia okislitelnaia fiksatciia molekuliarnogo azota perekisiu vodoroda //Tez. Docl 4-go Mezhdunar. Simpoziuma po gomogen. katalizu. L.: Nauka, 1984. T. 2. S. 133.

14. Nagiev T.M. The Coupled Reactions of Oxidation by Hydrogen Peroxide // Russian Chemical Reviews. Uspexi khimii. 1985. V. 54. № 10. P. 1654-1673 (in Russian).

15. Aleshin V.V., Shirokova G.N., Rosolovskii V.Ia. Giponitraty shchelochnykh metalov // Zhurn. neorgan. himii. 1981. T. 26. № 8. S. 2051-2058.

16. Partington J.R., Shach C.C. CCLXXXIIinvestigation on Hyponitrites. Part I. Sodium Hyponitrite: Preparation and Properties //J. Chem. Soc. 1931. V. Pt. II. P. 2071-2075.

17. Hugnes M.N. and Stedman G. The Mechanism of the Oxidation of Nitrous Acid by Hyponitrous Acid. Part I. //J. Chem. Soc. 1963. V. 8. P. 42304236.

18. Nagiev T.M., Zokhrabbekov S.Z., Shakhtakhtinskii T.N. Sopriazhennaia okislitelnaia fiksatciia molekuliarnogo azota // Docl. AN SSSR. 1987. T. 292. № 6. S. 1392-1395.

\section{AZOTUN ӘLAQӘLİ (QOŞULMUŞ) OKSIDLLŞMӘ İLə FIKKSASIYYASI T.M.Nağıyev, N.İ.Đli-zadə, L.M.Həsənova, İ.T.Nağıyeva, C..Đ.Mustafayeva, N.N.Məlikova, A.Ә.Abdullayeva, E.S.Bəhrəmov}

Azotun hidrogen peroksidlə oksidləşməsinin prinsipinin tədqiqi tamamilə yeni metodla nisbətən mülayim şəraitdə azotun fiksasiyasını həyata əsas etibarı ilə azot-1 oksidin və az miqdarda digər oksidlərin, həmçinin azot turşularının alınmasına imkan verir. Azotun hidrogen peroksidlə qaz fazalı oksidləşməsi mürəkkəb xarakter daşıyır və ilk anda azot-1 oksidin alinmasından ibarətdir. Alınan bu qaz yüksək temperaturlu reaksiya zonasından çıxarkən qaz halında reaksiya məhsulları qarışı̆̆ında ikinci çevrilmələrə məruz qalır və kəskin soyudulma şəraitində $\mathrm{H}_{2} \mathrm{~N}_{2} \mathrm{O}_{2}$ və digər azot turşuları alınır.

Açar sözlor: azot, fiksasiya, hidrogen peroksid, azot-1 oksid, nitrit turşusu.

\section{ФИКСАЦИЯ АЗОТА ПРИ СОПРЯЖЕННОМ ОКИСЛЕНИИ}

Т.М.Нагиев, Н.И.Али-заде, Л.М.Гасанова, И.Т.Нагиева, Ч.А.Мустафаева, Н.Н.Меликова, А.А.Абдуллаева, Э.С.Бахрамов

С использованием нового принципа окисления азота пероксидом водорода совершенно новым путем осуществлена фиксация азота в основном в виде $\mathrm{N}_{2} \mathrm{O}$ и других оксидов с незначительными примесями, а также азотсодержащих кислот в сравнительно мягких для подобного типа реакций условиях. Показано, что газофазное окисление азота пероксидом водорода носит сложный характер и состоит из первичной реакции образования закиси азота, которая при выходе из реакционной (высокотемпературной) зоны в составе газообразной реакционной смеси вступает во вторичные реакции с ее компонентами и в условиях резкого охлаждения образует кислоту $\mathrm{H}_{2} \mathrm{~N}_{2} \mathrm{O}_{2}$ и другие азотные кислоты.

Ключевые слова: азот, фиксация, пероксид водорода, закись азота, азотистая кислота. 